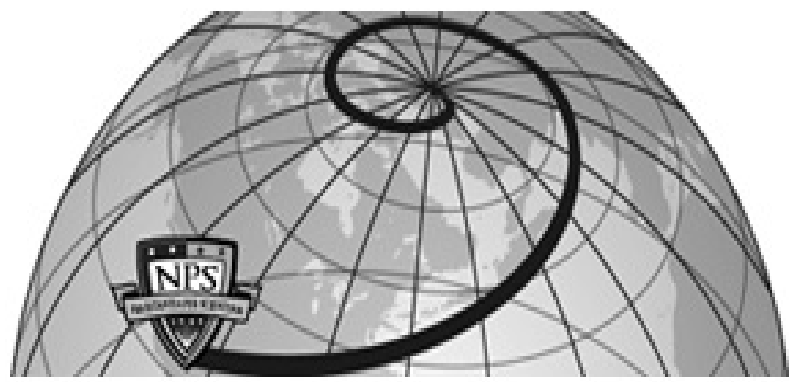

Calhoun: The NPS Institutional Archive DSpace Repository

\title{
Forging an Arctic Alliance Canadian-U.S. JIATF-Arctic
}

Bradley, Douglas A.

Naval Postgraduate School (U.S.)

Culture and Conflict Review (Earth Day 2011), v.5 no.2

https://hdl.handle.net/10945/27361

This publication is a work of the U.S. Government as defined in Title 17, United

States Code, Section 101. Copyright protection is not available for this work in the United States.

Downloaded from NPS Archive: Calhoun

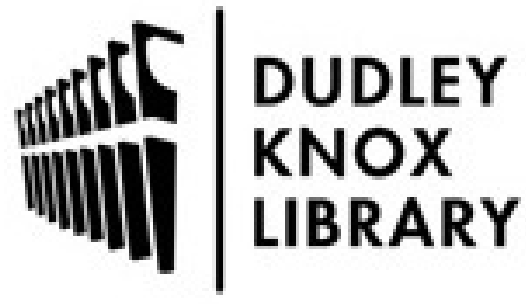

http://www.nps.edu/library
Calhoun is the Naval Postgraduate School's public access digital repository for research materials and institutional publications created by the NPS community. Calhoun is named for Professor of Mathematics Guy K. Calhoun, NPS's first appointed -- and published -- scholarly author.

Dudley Knox Library / Naval Postgraduate School 411 Dyer Road / 1 University Circle Monterey, California USA 93943 


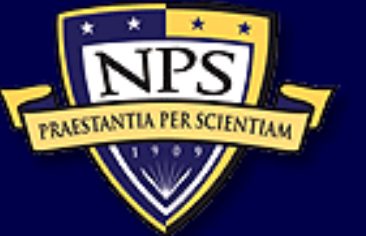

* Program for Culture \& Conflict Studies Home

\# About Us

* Provincial Overview

* Journal

* Research

* CCS People

* Contact Us

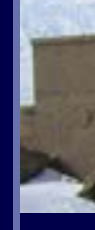

\section{Program for Culture \& Conflict Studies}

Home | Admissions | Academics | Research | Technology | Library | Administration | About NPS

CALENDAR | DIRECTORY SEARCH

H." $\underline{\text { Home }} \gg$ Culture \& Conflict Studies $\gg$ Welcome

\section{THE CULTURE AND CONFLICT REVIEW}

\author{
Forging an Arctic Alliance: Canadian-U.S. JIATF-Arctic \\ CDR Douglas A. Bradley, USN, 4/22/2011
}

\section{Introduction}

In 1867, Secretary of State William Seward purchased Alaska securing America's place with Russia, Norway, Denmark, and neighboring Canada as an Arctic nation.[1] Though criticized as "Seward's Ice Box," in short time, Alaska became a strategic asset, holding great natural resources and a vital defensive position on the North American continent. For over one hundred forty years, U.S. and Canadian national security interests in the Arctic have evolved into a more mature cooperative relationship through the Klondike gold rush, World War II, and The Cold War. Throughout each security challenge, the ice and extreme Arctic conditions always served as a natural defense denying direct maritime access to the continent's northern approach.[2] In August 2007, this assumption was no longer valid when the Northwest Passage opened ice-free, validating various Arctic ice recession models.[]] The effects of climate change creating an Arctic maritime domain have significant new political, military, economic, environmental, and scientific ramifications that require a whole-of-government response. Due to the unique nature of the Arctic region, shared interests, and historical bi-national defense relationship, the Arctic represents a theater for the next phase of greater Canadian and U.S. (CANUS) defense cooperation. A combined Joint Interagency Task Force Arctic (CJIATF-A) under alternating leadership, will best enable a COCOM to address the complexities of the changing Arctic region to promote responsible growth, regional stability, and continental security.

\section{A Growing Defense Partnership in the Arctic}

U.S. and Canadian Arctic security interests first collided during the resource rush of the late 1800s when miners and whalers dared the harsh conditions, necessitating Canadian Royal Mounted Police forces to promote stable growth and protect the native Inuit populations.[4] While this period was short lived, it showed that given sufficient promise for economic gain, investors and developers would come. U.S. and Canada Arctic defense cooperation was first unified after the Japanese invasion of Alaska in World War II, which erased the perceived notion that the vast, harsh Arctic environment would balance lack of military force. Together, leadership entered a cooperative effort building a logistics infrastructure via the "Alaska Highway," jointly involving over 40,000 U.S. military personnel working with Canadian civilians in the Northwest Territories.[5] This large-scale cooperation was only achievable through a combined U.S. Canadian effort and proved that national sovereignty could be maintained while still enabling U.S. integration, investment, and development on Canadian land.[] ]

The Cold War threat of Soviet bombers, submarines, and land-based inter-continental ballistic missiles once again defeated the notion that the icy Arctic hedged the North American continent from threat, renewing a cooperative U.S. -Canadian defense strategy in the high north. Working together for cooperative defense, the Distant Early Warning Line radar network, $75 \%$ of which was on Canadian land, was financed through the U.S., built with Canadian labor, and major sites commanded by Canadians.[7] Canadian sovereignty was maintained and unity of effort was attained, setting the foundation for the successful bi- national North American Aerospace Defense (NORAD) agreement. While this was a significant step in bi-national cooperation, it was centrally focused on air defense against external threats, avoiding land and maritime cooperation. The terrorist attacks of 9/11 served as the catalyst for re-organizing both U.S. and Canadian military commands and homeland security agencies, highlighting the need for greater cooperation and information sharing to reduce seams against 
continental threats.[] In 2004, speaking of U.S. and Canadian relations, former President Bush stated "we share the same values: freedom and human dignity and treating people decently" and subsequently issued a joint statement with Canadian Prime Minister Paul Martin stressing the need for greater binational cooperation for security to include greater intelligence sharing, infrastructure security, and expanding the NORAD mission to the maritime domain.[9] The subsequent 2006 NORAD agreement further advanced relations adding "maritime warning," but unlike air defense, only opened intelligence sharing and warning of threat, not an integrated maritime defense response.[10]

The Bi-National Planning Group for enhanced U.S.-Canadian military cooperation concluded a comprehensive four-year study stating the need for greater cooperation with the goal to "achieve the level (although not necessarily the form) of cooperation that now exists in NORAD in all other domains. This vision should be implemented by a Canada - United States „Comprehensive Defense and Security Agreement,. with a continental approach to CANUS defense and security while maintaining an open invitation to participation by other countries."[11] In addition to the strong bi-national NORAD agreement, the U.S. and Canada are partners in NATO, have recently exercised land force interoperability in Afghanistan, and

have deployed as components of U.S. Carrier Strike Groups.[12] The history, common interests, proven land and maritime interoperability, and shared values underwrite the tenants of respect, rapport, knowledge of partners, and patience necessary to achieve unity of effort for a greater security and defense partnership in the Arctic.[1]

\section{Changes in Arctic Theater Space - Re-framing the Problem}

Scientific observations of the northern ice cap show a steady recession trend and decline in ice thickness since 1979, with projections of completely ice-free passages through the Arctic during the summer months in as little as twenty years.[114] Much like the late 1800's gold rush, national and global economic interest in the Arctic has surged over the last decade, fueled by the promise of oil, natural gas, and precious mineral resources and access to a new global maritime highway. U.S. Geological Survey projections indicate the Arctic region potentially holds $13 \%$ of the oil reserves and $30 \%$ of the natural gas reserves, while the Arctic seabed is believed to harbor gold, silver, copper, and diamonds, thus generating significant interest from private industry to obtain drilling rights as well as from regional governments seeking to establish exclusive territorial boundaries.[15] The ice-diminished passages also have the potential to create vital shipping lanes, reducing the length of Asian- European maritime routes up to $40 \%$ and relieving congestion or providing a strategic bypass around more vulnerable choke points such as the Suez Canal, Panama Canal, and the Strait of Malacca.[16] Like the 1800's whaling industry, the melting ice may attract commercial fisheries from around the world seeking food stocks for their growing nations. Ice recession and subsequent warming water temperatures may shift some fish species habitats further north and uncover new fishing grounds previously inaccessible.[17] In addition to commercial industry, Arctic tourism is thriving. The 2009 Arctic Marine Shipping Assessment reported that visitors to the Arctic more than doubled the 2004 figure of 1.2 million in 2007 and 8 transits of the Northwest Passage were planned for 2008 alone.[18] Unlike the past Arctic history, the Arctic region holds a maritime future. In 2004 alone, approximately 6,000 vessels were counted within Arctic waters, the majority of which were community re-supply, bulk cargo, tourism, and fishing vessels.[19]

This commercial maritime expansion presents new threats and concerns. Increased oil and gas resource development risks ecological disaster like the BP Gulf of Mexico or Exxon Valdez incidents, while increased maritime traffic brings risk of environmental impact, accidents at sea, pandemic illness, impact on indigenous nations, and fisheries control, necessitating a timely and effective government response capability.[20] Various maritime and environmental safety risks and capacity of Arctic nation response were examined by the Coastal Response Research Center who reported several capability, infrastructure, and cross-border issues response gaps.[21] In addition to maritime safety concerns, a Northern Ocean route supporting global commerce traffic opens the North American continent to security and criminal threats including terrorist attack at-sea, piracy, illegal immigration, and smuggling.[22]

In 2009, the U.S. defined an Arctic strategic policy in National Security Presidential Directive 66/Homeland Security Presidential Directive 25 outlining six policy objectives in response to the changing problem frame:

1. Meet national security and homeland security needs.

2. Protect the Arctic environment and conserve its biological resources. 
3. Environmentally sustainable resource management and economic development.

4. Strengthen institutions for cooperation among the eight Arctic nations.

5. Involve the Arctic's indigenous communities 6. Enhance scientific monitoring and research.[23]

To achieve the national objectives, the U.S. Navy advanced their Arctic Roadmap in 2009, defining a path through FY2014 to address capability deficiencies while also expressing the need to develop joint, interagency, and international cooperative partners.[24] In support of developing a U.S. Coast Guard Arctic roadmap, U.S.C.G. District 17 conducted a "High Latitude Survey" identifying significant small boat, cutter, and infrastructure deficiencies to meet national objectives for Arctic operations.[25] Despite this testimony to Congress and the known need to replace the aging U.S. icebreakers, the U.S. President FY-11 budget for the Coast Guard does not address any of these shortfalls or infrastructure projects for the Arctic and cuts a USCG Maritime Safety and Security Team (MSST) in Alaska.[26] U.S. maritime capability and infrastructure is currently insufficient to meet the broad goals articulated by NSPD66/HSPD25 and will be challenged to attain proper support with future defense budget reductions.[27]

The Canadian government and military also continued forward, issuing a new Arctic strategy in 2009 with four main objectives - promoting national sovereignty, responsible development, environmental preservation, and good regional governance.[28] Supporting their objectives to assert sovereignty, the Canadian military completed a robust multi-national joint training exercise, Operation NANOOK, in August 2010, involving over 1,000 military personnel, state agencies, government organizations, and naval vessels from the United States and Denmark under the command of Canadian Joint Task Force North.[29] The Task force exercised the ability to respond to a number of security, safety, and emergency situations including an oil spill disaster exercise, and establishing their first Canadian Force Arctic Maritime Component Commander.[30] Canada's Northern Strategy outlined numerous other initiatives to build an Arctic capable force including a new cold weather military training facility, deep water Arctic port for extended reach, six to eight Polar Class 5 patrol ships, a new heavy icebreaker, and RADARSAT-II surveillance satellites.[31] Though a significant step to capability, Canada still lacks under-ice capability, continuous surveillance, and existing capacity to protect Arctic interests unilaterally.[32]

The evidence presented by the U.S. Coast Guard's Congressional Reports, Navy Arctic Roadmap, and the Canadian Standing Committee on National Defense all highlight inadequate force capabilities to unilaterally safeguard against the growing variety of threats in the vast spaces of the Arctic. The problems of forward presence and basing, arctic capable ships, intelligence sharing, communications systems, maritime awareness, arctic trained military personnel, interagency liaison, and federal presence present an opportunity for each country to work together for common solutions from the beginning. Examining both U.S. and Canadian Arctic maritime capabilities, one analysis concluded "a unilateral approach to Arctic security will surely prove more costly and less effective over the long term."[33] The Center for International Studies also stated "No one Arctic nation has the capacity to cover the whole geographic area to respond to soft and hard security challenges." By leveraging national strengths and building on a historical solid bi-national partnership, U.S. and Canada should develop a Combined Joint Interagency Task Force Arctic (CJIATF-A) to proactively achieve unity of command and effort in the Arctic.

\section{Balancing the Factors with Function: Forming CJIATF-Arctic}

In developing a construct for CJIATF-A, CJCS Joint Publication 3-33 Joint Task Force Headquarters outlines the following establishing authority responsibilities: appointing the commander, determining military forces and other national means required, providing the overall mission, and defining the Joint Operating Area (JOA).[34]

Defining the Mission. The scope of the NSPD66/HSPD25 Arctic Region Policy covers a wide range of military missions including traditional national security interests of missile defense, strategic deterrence, global mobility, maritime security, countering homeland security terror threats and maritime law enforcement.[35] However, it also includes several non-traditional military focus areas including resource management, environmental protection, economic development, scientific studies, commercial maritime safety, and border management, requiring a number of different government departments and agencies to achieve unity of effort.[36] Canada's Northern Strategy articulates similar principles. By combining shared national interest for the region, CJIATF-A's mission would notionally be to plan, conduct, and direct assigned bi-national forces and interagency partners to maintain freedom of Arctic maritime navigation, provide North American homeland and maritime security, law enforcement, 
maritime safety, environmental protection, responsible resource and economic development, scientific studies, and consequence management within the defined Arctic AOR; maintain a combined joint intelligence operations center, air and maritime common operating picture, and high latitude C4I network to effectively share information across bi-national forces and interagency groups to coordinate operations.

Defining Establish Authority. The 2006 Bi-national Planning Group (BPG) Final Report outlined four models for future U.S.-CAN defense command and control integration that offer potential application to a CJIATF-A concept.[37] These models are based on a larger scope than Arctic cooperation, but offer two key applications. First, the natural nexus of overall command for a CJIATF-A should be established under NORTHCOM/NORAD based the long-standing history of bi-national partnership with CANCOM through NORAD. Second, NORAD's role should expand to become an all-domain warning, surveillance, and control command, adding maritime warning to effectively unify effort and bi-national response to a maritime threat. Combining BPG concepts 1 and 4, a hybrid solution (Figure 1) offers a possible construct to establish a CJIATF-A under NORAD, leveraging the advantages of models 1 and 4 . In the hybrid construct, NORTHCOM, CANCOM, and NORAD would retain current relationships with NORAD becoming an all-domain warning and control command. An updated NORAD bi-national agreement would provide the authority to establish a standing CJIATF-A capable of bi-national action. CJIATF-A would support both national defense commands and homeland security departments for unity of effort for the Arctic mission with each national command retaining unilateral action for security and defense.

Defining the JOA. Though the Unified Command Plan divides the Arctic area between NORTHCOM, EUCOM, PACOM, the mission and operating space for CJIATF-A could fit within the NORTHCOM and CANCOM boundaries with a few modifications.[38] As an interagency command, the JOA should represent a combination of existing command areas and scientific research Arctic areas. The U.S. Research and Policy Act of 1984 includes areas of Alaska below the Arctic Circle including the Aleutian Island Chain and Bering Sea (Figure 3).[39] This area overlaid on the Unified Command Plan and Canadian Command Organization yield an Arctic JOA stretching from the NORTHCOM Greenland boundary to Russia, including Alaska, the Aleutian Islands, and the Bering Sea. From north to south, the area would cover from the current NORTHCOM/EUCOM/PACOM border down to the 60th parallel in Canada, aligning with the southern boundary of Canada's Arctic command, JTF- North (Figure 4).[40] The Arctic JOA would encompass the North American Arctic seabed, Northwest Passage maritime route, Alaska, and Canadian Arctic lands. This proposal would require a change to the UCP assigning the Bering Sea area to NORTHCOM while allocating the remainder of the PACOM Arctic Area to EUCOM (Figure 5). This would eliminate one Arctic COCOM seam, placing the Northern Sea Arctic maritime route and European Arctic nations under EUCOM and NATO alliance responsibility. Ice melt predictions still indicate the polar ice will remain at least until 2030, leaving a natural barrier between these two regions and sufficient time to re-evaluate the environment, missions, and threats for future changes.

\section{Organization Command and Control}

Though under military command, the nature of CJIATF-A missions will include many non-traditional military roles similar to JIATF-South's focus on the counter-narcotics mission. JIATF-South serves as a model for effectively integrating numerous intergovernmental agencies, law enforcement, intelligence, international partners and military assets operating across all domains in an area five times the size of the U.S.[41] Their mission success offers three lessons learned for building CJIATF-A. First, to facilitate transition across defense and homeland security domains with law enforcement experience, U.S. command may be best conducted under Coast Guard leadership; second, the mission must be clearly defined to achieve full interagency partnership; and third, interagency members should be integrated into staff leadership positions for unity of effort.[42] Though USCG command is not a requirement, it offers several advantages for integrating defense, maritime security and safety, and law enforcement missions. The Canadian Defense forces have an established Arctic presence through JTF-North under army command, coordinating a network of Arctic land forces, indigenous Rangers, and logistics assets.[43] To achieve maximum unity of command and to build trust, CJIATF-A should employ an integrated command structure with a rotational command alternating between Canada and U.S. commanders every 2 years.[44] Like the NORAD model, the deputy should be a military commander from the other nation. A U.S. Coast Guard Admiral and Canadian Army General rotating command and deputy duties may provide the best combination of maritime and land force experience for unified effort across the Arctic space.

The CJIATF-A organization must be a collaborative, cooperative, coordinating command to achieve unity of effort. The command should be staffed in a Joint Task Force directorate model with a full 
spectrum of bi-national defense, intelligence, law enforcement, environmental, scientific, local government agencies, and NATO military liaison officers. Bi-national participants within the command, grouped by function should include:

- State Department/Foreign Affairs - U.S. and Canadian Arctic Council liaisons.

- Department of Defense (DOD)/Canadian Department of National Defense - U.S. Army, Navy, Air Force, Coast Guard, Marine Corps; Canadian Army, Navy, Air Force, Coast Guard, Rangers.

- Intelligence - U.S. DIA, CIA, NSA, NGA, NRO; Canada Security Intelligence Service, Canada Integrated Threat Assessment Center.

- Law Enforcement - U.S. FBI, Customs and Border Protection, Alaska State Police; Royal Canadian Mounted Police, Canada Border Services.

- Maritime Transportation - U.S. Department of Transportation; Canada Transportation Agency.

- Environment - U.S. Department of Interior's Bureau of Ocean Energy Management, Regulation and Enforcement (BOEMRE), Environmental Protection Agency; Canada Indian and Northern Affairs Council, Fisheries and Oceans Canada, Natural Resources Canada, Canada National Energy Board.

- Scientific Research - NOAA, NASA, NSF, U.S. Arctic Research Commission (USARC); Canada Ice Service.

- NATO Military Liaisons - Denmark Navy, Norway Navy.

- State and Native Government Liaisons - Alaska, Alaskan Native Tribal Government, Alaska National Guard; Canada Governments of Northwest Territories, Yukon, Nunavut.[4ㄷ]

A notional staff organization (Figure 2) would follow a typical JTF staff organization outlined in CJCS Joint Publication 3-33 adding a fused intelligence J-2 directorate and a Joint Interagency Coordination Group (JIACG) headed by the State Department/Foreign Affairs Representatives. The JIACG would comprise the non-defense and security agencies grouped by functional area including environment, scientific research, state government and native government liaisons. The J-3 operations directorate would fuse DOD/DND, law enforcement, NATO military liaisons, and a NORAD all-domain warning and control liaison for action across the defined mission areas.

\section{The Impossible Command?}

Critics against a standing bi-national interagency Arctic command will point to several vulnerabilities for success including threat to national sovereignty, unresolved disputes over the Beaufort Sea and Northwest Passage, missions too broad to achieve unity of effort, and no national support to change. Canada has long regarded their northern Arctic front as their unique and sovereign domain.[46] This strong national claim is the first pillar in Canada's Northern Strategy, backed by a planned commitment to Arctic defense spending and capacity building. To ensure popular support in both nations, the command arrangement must not interfere with either nation's ability for unilateral action to protect national sovereignty.[47] Forming a CJIATF under the authority of the existing bi-national NORAD command will provide the structure and agreeable framework necessary to protect sovereignty under a concept largely popular in Canada.[48] Additionally, alternating CJIATF- A command between nations focusing on shared principles of both national strategies will potentially promote greater cooperation.

Opening of Arctic maritime passages also ignites long-standing differences held between Canada and the U.S. over continental shelf claims in the Beaufort Sea and the status of the Northwest Passage as an international strait.[49] Some may argue that these differences would prevent the respective governments from building a command purposed with maritime security and freedom of navigation. Both nations seek to resolve these issues but neither issue should prevent greater cooperation. Over the last year, U.S. and Canadian icebreakers and scientists have worked cooperatively to survey the Beaufort Sea floor to establish extended continental shelf claims under the terms of UNCLOS Article 76 . This issue will eventually be resolved by scientific data and only presents short-term challenges for future resource development.[50] More problematic is Canada's claim to the Northwest Passage as internal waters through excessive baselines not supported by UNCLOS and "historical internal waters" claims that also do not meet UN defined criteria.[51] To best maintain national sovereignty and meet national environmental protection objectives CDR James Kraska, Judge Advocate General's Corps, United States Navy, suggests, "The best recourse is for Canada to seek international recognition and acceptance of some variation of its rules and regulations for transiting the area- effectively obtaining "buy in" from the international community."[52] Further, some Canadian Arctic experts propose "Canada can head off an unseemly contretemps by working with the U.S. to develop a shared strategy for the control, regulation, and use of the Northwest Passage."[53] The U.S. and Canada will likely continue to debate the Northwest Passage issue, "agreeing to disagree," but will not allow the issue to disrupt 
military cooperation.[54] In the long-term, a combined approach will benefit Canadian interests for a peacefully regulated Arctic passage.

JIATF-South's success was in part attributed to a narrowly focused mission, in which all partners shared a direct interest.[55] The proposed CJIATF-A mission is broader where some agencies will not be involved across all areas. The risk inherent in the broad mission objectives is creating a hierarchy of priorities, potentially marginalizing some partners and losing their trust when they perceive their interests are not being served and protected by the command.[56] The bi-national, rotational command and incorporation of interagency partners into leadership roles should serve to mitigate this risk. In addition, like JIATF-South, a CJIATF-A command should be physically located in one location (in Canada) to best facilitate personal relationships and cooperative trust.[57]

The most persuasive argument may be to maintain the national status quo. The recent Arctic policy push was predicated on ice data only collected since 1979 , and it is possible that the Arctic could ice over again given the complexity of the variables involved.[58] U.S government agency policies have been established restricting commercial fishing above the Arctic Circle and delaying petroleum drilling exploration off the Alaska northwest coast for the near future to conduct additional environmental impact studies and consequence management capabilities, dampening an early rush of activity.[59] The Arctic space still provides a viable defense against significant commercial activity and scientific trends indicate at least 10 years before the summer ice melt provides extended periods of access in the region. Further, both nations have established numerous non-defense initiatives through the Arctic Council, share a tripartite search and rescue agreement, and each have Arctic based JTF's through JTF-Alaska and Canada Joint Task Force-North that cross over several of the proposed missions of CJIATF-A. Why stray from the unilateral approach? History has shown that an enemy will exploit vulnerabilities and throughout the last century, both Canada and the U.S. have always reacted to threats in this region. In 2000, Canadian Intelligence Services reported over 50 foreign terrorist organizations including Al Qaeda, operating within Canada, capitalizing on the close proximity to the U.S. to stage and conduct attacks.[60] Opening a northern maritime domain changes previous defense and security assumptions enabling potential terrorist threat movement or action in the Arctic placing soft targets such as shipping, petroleum and gas facilities, and the continent at risk with catastrophic consequences. Functioning as a bi-national command across this vast space will reduce seams for coordinated security action. Rear Admiral Dave Titley, Oceanographer of the Navy and Director of Task Force Climate Change, discussing the recent USS Porter participation in Canadian Arctic military exercise Natsiq, remarked that "Partnerships will help us prepare for these new challenges more effectively and with less cost, that includes partnerships with federal agencies like the U.S. Coast Guard and NOAA, and also with other nations."[61] U.S. and Canadian partnerships developed for Arctic continental defense, aerospace defense, and post-9/11 continental security show greater success and unity of effort when developed binationally. The unique missions in the Arctic are ideally suited for a CJIATF-A.

\section{Recommendations and Conclusions}

Several recommendations follow to develop this command. To minimize COCOM seams, the UCP should be modified to split the Arctic AOR between NORTHCOM and EUCOM, and the Bering Sea area added to NORTHCOM responsibility. The NORAD agreement should be revised to add maritime control and formally establish the CJIATF-A as a bi-national standing Joint Task Force supporting NORAD. A physical headquarters should be identified to co-locate partner representatives and liaisons, possibly using either the existing infrastructure at CANCOM's JTF-North or NORTHCOM's JTF Alaska, in cooperation with NORAD Alaska. The command should conduct a comprehensive bi- national review of capabilities, assets, and infrastructure, while developing a coordinated plan for future force building, deep water ports, communications systems, logistics infrastructure, and force interoperability.

Each nation has taken positive steps defining a strategy for the Arctic, sharing many of the same goals. Building a bi-national CJIATF-A under NORAD will best coordinate the whole of government approach for NORTHCOM and CANCOM as articulated within both national Arctic policy documents. By employing a rotating national commander and using principles from JIATF-South as a model for interagency command and control, CJIATF-A will achieve unity of command and unity of effort operating in the new Arctic space.

Figure 1 - Hybrid Concept: Combined JIATF-Arctic Under NORAD 


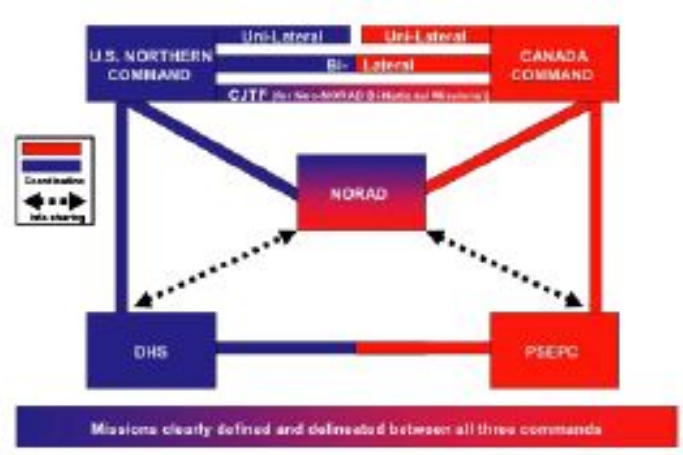

CONCEPT 1: THREE COMMANDS - COMPLEMENTARY MISSIONS

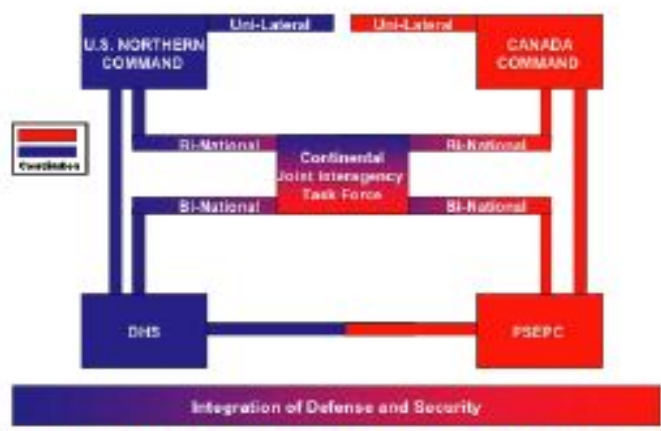

CONCEPT 4: CONTINENTAL INTERAGENCY JOINT TASK FORCE

(Source: Bi-National Planning Group The Final Report, March 2006)

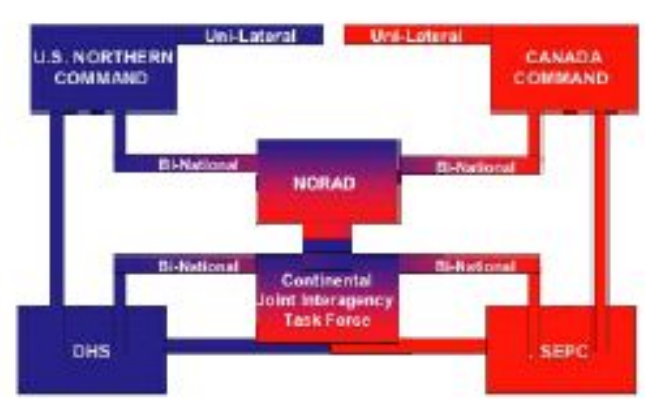

(Source: Bi-NationalPlanning Group The Final Report, March 2006)

Figure 2 - Notional CJIATF-A Command Organization

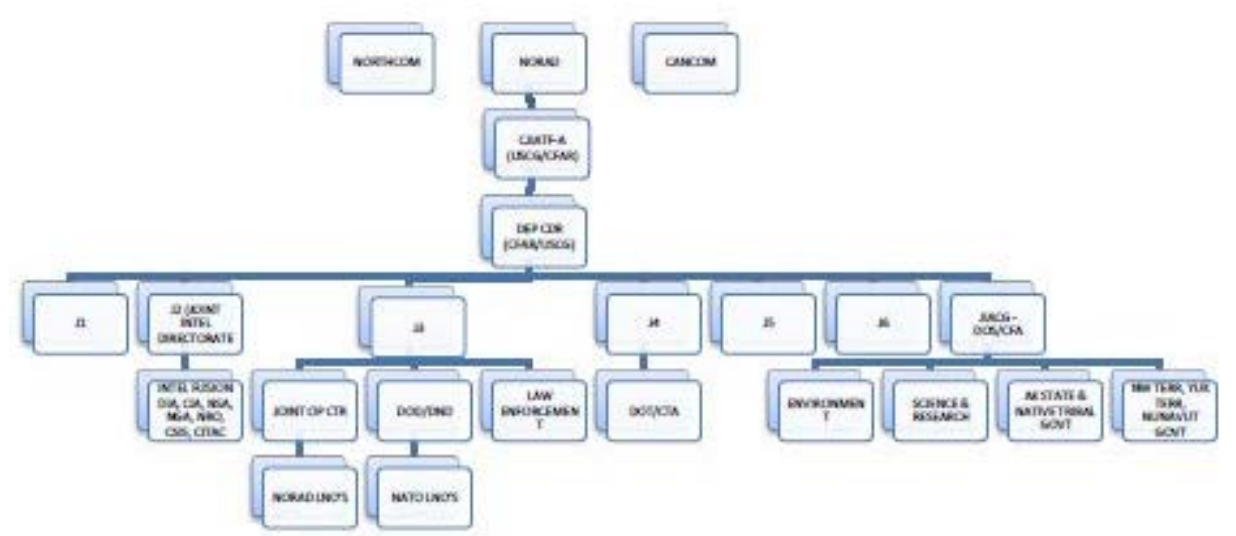

Figure 3: Map of Arctic Boundary as Defined by the Arctic Research and Policy Act 


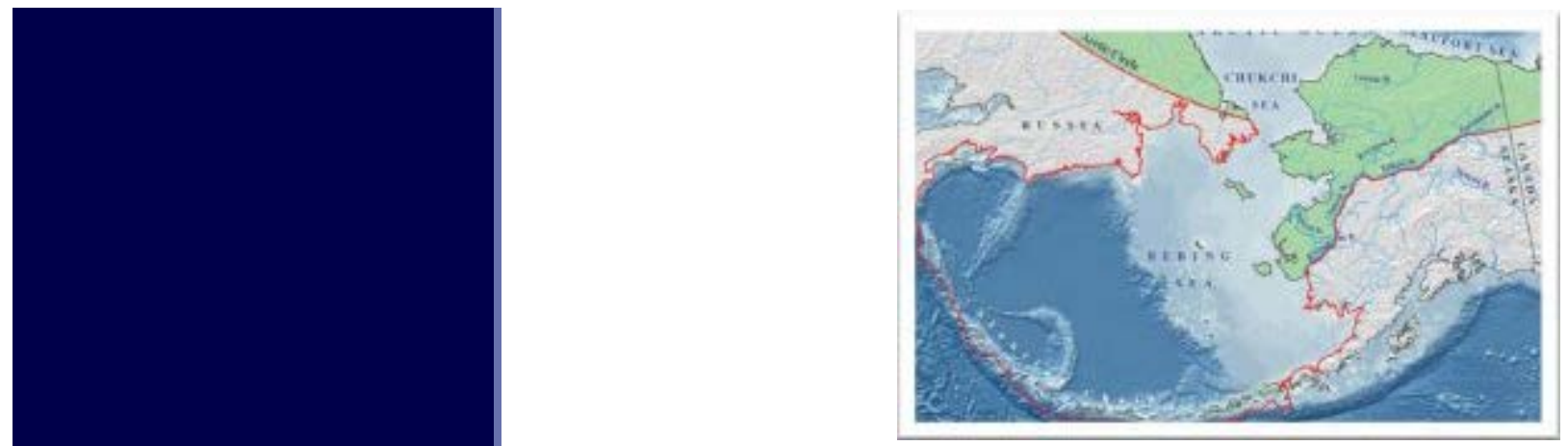

(Source: U.S. Government Accountability Office, Coast Guard 10-870, September 2010)

Figure 4: Map of Canadian Command Areas, JTF-NORTH

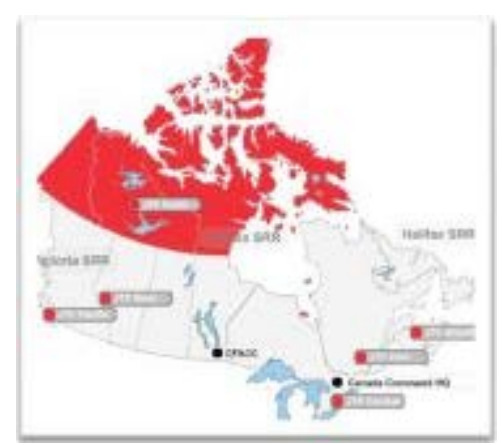

(Source: www.canadacom.forces.gc.ca/site/org-org-eng.asp, October 2010)

Figure 5 - Proposed CJIATF-ARCTIC JOA and UCP Update

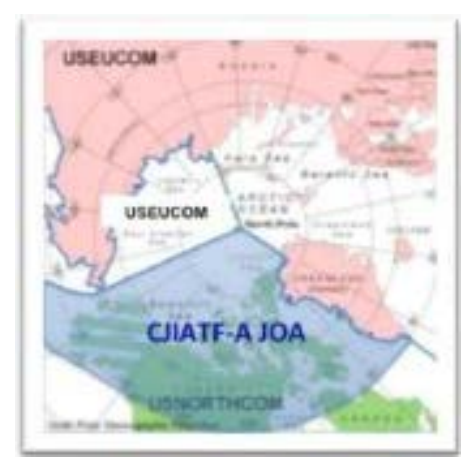

\section{References}

(All notes appear in shortened form. For full details, see the appropriate entry in the bibliography.)

1. Library of Congress, "Purchasing Alaska,"

http://www.americaslibrary.gov/jb/recon/jb_recon_alaska_1.html (accessed 12 October 2010)

2. Coates et al., Arctic Front, 4.

3. NSIDC, "State of the Cryosphere," http://nsidc.org/sotc/sea_ice.html (accessed 11 October 2010).

4. Coates et al., Arctic Front, 22,25.

5. Coates et al., Arctic Front, 57-59.

6. Ibid, 62.

7. Ibid, 71.

8. Bi-National Planning Group, Final Report, i. 
9. Inge and Findley, North American Defense and Security after 9/11, 24.

10. Regehr, NORAD renewal: Further Down the Slippery Slope, 2.

11. Ibid, 5.

12. Avis, "Seductive Hegemon."

13. CJCS, Multinational Operations JP 3-16, I-3,4.

14. NSIDC, "Weather and Feedbacks Lead to Third Lowest Extent," http://nsidc.org/arcticseaicenews/2010/100410.html, (accessed 12 October 2010).

15. Cohen, "From Russian Competition to Natural Resources Access: Recasting Arctic Policy."

16. Coates et al., Arctic Front, 148.

17. Gove, "Arctic Melt Reopening a Naval Frontier".

18. Arctic Council, Arctic Marine Shipping Assessment Report 2009, 79.

19. Ibid, 73.

20. Conley and Kraut, U.S. Strategic Interests, 7.

21. Coastal Response Research Center, Opening the Arctic Seas, 32-37.

22. Coates et al., Arctic Front, 149.

23. Arctic Region Policy, NSPD66/HSPD25.

24. VCNO, U.S. Navy Arctic Roadmap, 6, 10-11.

25. US GAO, Coast Guard Efforts to Identify Arctic Requirements Are Ongoing, 34.

26. Cohen, "From Russian Competition to Natural Resources Access," 5.

27. Patch, "Cold Horizons," http://www.usni.org/magazines/proceedings/2009-05/cold-horizons-arcticmaritime- security-challenges (accessed 11 October 2010).

28. Minister of Public Works and Government Services Canada (MPWGSC), Canada's Northern Strategy, 2.

29. Marketwire, "Operation NANOOK Reaches Successful Conclusion,"

http://www.marketwire.com/press- release/Operation-NANOOK-Reaches-Successful-Conclusion1310796.htm (accessed 13 October 2010).

30. Ibid.

31. MPWGSC, Canada's Northern Strategy, 10.

32. Patch, "Cold Horizons."

33. Patch, "Cold Horizons."

34. CJCS, Joint Task Force Headquarters, JP 3-33, I-2.

35. Arctic Region Policy, NPSD66/HPSD25.

36. Ibid.

37. BPG, Final Report on Canada and the United States, 36-40.

38. U.S. President. Unified Command Plan. Washington, DC: The White House, 23 December 2008. (FOUO).

39. U.S GAO, Coast Guard, 7. 
40. Canada National Defenses. "Organization," http://www.canadacom.forces.gc.ca/site/org-orgeng.asp\# , (accessed 12 October 2010).

41. Yeatman, "JIATF-South Blueprint for Success," 27.

42. Ibid, 26.

43. National Defence and the Canadian Forces, "The Canadian Forces in the North," http://www.cfna.dnd.ca/nr- sp/09-002a-eng.asp (accessed 20 October 2010).

44. CJCS, Multinational Operations, JP 3-16, II-6,7.

45. U.S. GAO, Coast Guard, 10-11.

46. Conley and Kraut, U.S. Strategic Interests, 16.

47. BPG, Final Report, 38.

48. BPG, Final Report, 37.

49. Conley and Kraut, U.S. Strategic Interests, 16.

50. Capt Stephen W. Jordon (Naval Attache U.S. Embassy, Ottawa, Canada), interview with the author 18 October 2010.

51. Kraska, "A Diplomatic Solution for the Northwest Passage," 2.

52. Ibid, 5.

53. Coates et al., Arctic Front, 203.

54. Capt Stephen W. Jordon (Naval Attache U.S. Embassy, Ottawa, Canada), interview with the author 18 October 2010.

55. Yeatman, "JIATF-S Blueprint for Success," 26.

56. Caswell, Establishment of the National Maritime Intelligence Center, 47.

57. Ibid, 48.

58. NSIDC, "State of the Cryosphere," http://nsidc.org/sotc/sea_ice.html. (accessed 11 October 2010). 59. U.S. GAO, Coast Guard, 6-7.

60. Library of Congress Federal Research Department, Asian Organized Crime in Canada, 28-29.

61. Freeman, "USS Porter Sets Sail for Arctic and the Future."

\section{Selected Bibliography}

Arctic Council. Arctic Marine Shipping Assessment 2009 Report. Norway: April 2009.

Arctic Council and Global Business Network. The Future of Arctic Marine Navigation in Mid-Century Scenario Narratives Report. Norway: March 2008.

Arctic Region Policy. National Security Presidential Directive/NSPD 66 Homeland Security Presidential Directive/HSPD-25, 9 January 2009. http://georgewbushwhitehouse.archives.gov/news/releases/2009/01/print/20090112- 3.html (accessed 10 September 2010).

Avis, Capt Peter. "Seductive Hegemon: Why Nato is Still Important to Canada." Canadian Military Journal 5 no.1 (July 2008). http://www.journal.forces.gc.ca/vo/no1/nato- otan-eng.asp (accessed 17 September 2010).

Bi-National Planning Group. The Final Report on Canada and the United States (CANUS) Enhanced Military Cooperation. Peterson AFB, CO: 13 Mar 2006.

Brigham, Lawson. "Navigating the New Maritime Arctic." US Naval Institute Proceedings 135/5/1,275 
(May 2009). http://www.usni.org/magazines/proceedings/2009- 05/navigating-new-maritime-arctic (accessed 11 October 2010).

Canada National Defenses. "Organization." http://www.canadacom.forces.gc.ca/site/org-org- eng.asp\# (accessed 12 October 2010).

Carafano, James. "A Better Way to Fight Terrorism." The Heritage Foundation. 17 May 2005. http://www.heritage.org/Research/Commentary/2005/05/A-Better-Way-to- Fight-Terrorism (accessed 13 October 2010).

Carman, Jessie C. "Economic and Strategic Implications of Ice-Free Arctic Seas." In Globalization and Maritime Power, edited by Sam J. Tangredi Washington, D.C.:NDU Press, December 2002, 173-189. https://digitalndulibrary.ndu.edu/cdm4/document.php? CISOROOT=/ndupress\&CISOPTR=27639\&REC=18 (accessed 10 October 2010).

Caswell Jr., Kenneth L. Establishment of the National Maritime Intelligence Center: Understanding the Foundations of Trust to Support a Collaborative Environment in Homeland Security. Monterey, CA. Naval Postgraduate School. March 2010.

CBC News. "Arctic Security Improvements Recommended." 17 June 2010.

http://www.cbc.ca/canada/story/2010/06/17/arctic-security-committee.html (accessed 12 October 2010).

Clarkson, Stephen and Erin Fitzgerald. "A Special Military Relationship? Canada's Role in Constructing U.S. Military Power." Journal of Military and Strategic Studies 12, Issue 1 (Fall 2009): 1-24.

Coastal Response Research Center. Opening the Arctic Seas Envisioning Disasters and Framing Solutions. Durham, NH: January 2009.

http://www.crrc.unh.edu/workshops/arctic_spill_summit/arctic_summit_report_final. pdf

Coates, Ken S., P. Whitney Lackenbauer, William R. Morrison, and Greg Poelzer, Arctic Front: Defending Canada in the Far North, Toronto: Thomas Allen, 2008.

Conley, Heather and Jamie Kraut. U.S. Strategic Interests in the Arctic. Center for Strategic and International Studies. Washington, DC. April 2010.

http://csis.org/files/publication/100426_Conley_USStrategicInterests_Web.pdf

Cohen, Ariel. "From Russian Competition to Natural Resources Access: Recasting U.S. Arctic Policy." The Heritage Foundation Backgrounder 2421 (15 June 2010). http://report.heritage.org/bg2421 (accessed 11 October 2010).

Council of the European Union. Council Conclusions on Arctic Issues. Brussels, Belgium: 8 December 2009. http://ec.europa.eu/maritimeaffairs/pdf/arctic_council_conclusions_09_en.pdf (accessed 11 October 2010)

Fellman, Sam. "Cutting Costs a Priority for 2011, CNO Says." Navy Times. 21 October 2010. http://www.navytimes.com/news/2010/10/navy-roughead-says-cutting-costs-is- 2011-priority-101810w/ (accessed 22 October 2010).

Freeman, Bob. "USS Porter Sets Sail for the Arctic and the Future." Navy.mil. 10 August 2010. http://www.navy.mil/search/display.asp?story_id=55230 (accessed 11 October 2010).

Graham, Ian. "Coast Guard Commandant Considers Alaska Presence." American Forces Press Service, Washington, DC, 3 September 2009. http://www.militaryconnection.com/news/september-2009/coastguard-alaska.html (accessed 11 October 2010).

Greenert, Adm J. W., Vice Chief of Naval Operations. U.S. Navy Arctic Roadmap. Washington, DC: VCNO, October 2009.

Gove, David. "Arctic Melt: Reopening a Naval Frontier." US Naval Institute Proceedings 135/2/1,272 (February 2009). http://www.usni.org/magazines/proceedings/2009-02 (accessed 17 September 2010).

Holroyd, Suzanne M. U.S. and Canadian Cooperative Approaches to Arctic Security, RAND Note N3111-RC, Santa Monica, CA: RAND, June 1990.

House of Commons Canada. Canada's Arctic Sovereignty Report of the Standing Committee on 
Huebert, Rob. "Canadian Arctic Maritime Security: The Return to Canada's Third Ocean," Canadian Military Journal 8 no.2 (July 2008). http://www.journal.forces.gc.ca/vo8/no2/huebert-eng.asp (accessed 10 October 2010).

Huebert, Rob. "Renaissance in Canadian Arctic Security." Canadian Military Journal 6 no.4 (July 2008). http://www.journal.forces.gc.ca/vo6/no4/north-nord-eng.asp (accessed 10 October 2010).

Inge, Joseph R., and Eric A. Findley. "North American Defense and Security After 9/11," Joint Forces Quarterly 40, (1st Qtr 2006): 23-28. http://www.dtic.mil/cgi- bin/GetTRDoc?

Location=U2\&doc=GetTRDoc.pdf\&AD=ADA521750 (accessed 7 October 2010).

Johnson, Spencer W. "New Challenges for the Unified Command Plan." Joint Forces Quarterly, (Summer 2002): 62-70.

Keating, Adm Timothy. Transcript. Atlantic Council, 29 June 2009. http://www.acus.org/event/admiraltimothy-keating-asia-pacific-security- challenges/transcript (accessed 10 October 2010).

Kefferputz, Roderick and Danila Bochkarev. Expanding the EU's Institutional Capacities in the Arctic Region Policy Briefing and Key Recommendations. Brussels, Belgium: Heinrich Boll Stiftung. http://www.boell.ru/downloads/Arctic_Web-Version-3.pdf (accessed 11 October 2010).

Kraska, James. "A Diplomatic Solution for the Northwest Passage." National Strategy Forum Review, 19/3 (Summer 2010)

http://nationalstrategy.com/Portals/0/documents/Summer\%202010\%20NSFR/James\%20Kraska\%20\%20Summer\%202010\%20NSFR.pdf (accessed 25 October 2010).

Leggiere, Phil. "Coast Guard Expanding Arctic Presence." Homeland Security Today. 24 August 2009. http://www.hstoday.us/content/view/9912/149/ (accessed 11 October 2010).

Leggiere, Phil. "The Arctic Heats Up As Security Focus." Homeland Security Today. 11 August 2008. http://www.hstoday.us/content/view/4655/149/ (accessed 11 October 2010).

Lerhe, Eric. "Will We See A Maritime NORAD?" Journal of Military and Strategic Studies 8, Issue 4 (Summer 2006): 1-17.

Library of Congress: America's Story from America's Library. "Purchase of Alaska." http://www.americaslibrary.gov/jb/recon/jb_recon_alaska_1.html (accessed 12 October 2010).

Malenic, Marina. "U.S. Military Wants Fresh Look At Arctic Policy." Defence Daily, 18 December 2008. http://byers.typepad.com/arctic/2009/01/us-military-wants-fresh- look-at-arctic-policy.html (accessed 11 October 2010).

Marketwire. "Operation NANOOK Reaches Successful Conclusion." Ottawa, Ontario: 27 August 2010. http://www.marketwire.com/press-release/Operation-NANOOK- Reaches-Successful-Conclusion1310796.htm (accessed 13 October 2010).

Maurer, Martha E. Coalition Command and Control Key Considerations, Washington, D.C.: National Defense University, 1994.

Minister of Public Works and Government Services Canada. Canada's Northern Strategy Our North, Our Heritage, Our Future. Ottawa, Canada: 2009.

Moran, Kate. "NSTC to Coordinate Certain Arctic Research Policy Committee Activities," Office of Science and Technology Policy, 23 August 2010. http://www.whitehouse.gov/blog/2010/08/23/nstccoordinate-certain-arctic-research- policy-committee-activities (accessed 11 October 2010).

NASA. "A Snapshot of Sea Ice." NASA.gov, 13 September 2010.

http://www.nasa.gov/topics/earth/features/ice-min-approach.html\# (accessed 11 October 2010).

National Defence and the Canadian Forces. "The Canadian Forces in the North." Canada Command Backgrounder BG \#09.002A, Ottawa, Canada: (17 April 2009) http://www.cfna.dnd.ca/nr-sp/09-002aeng.asp (accessed 20 October 2010). 
National Snow and Ice Data Center. "State of the Cryosphere." http://nsidc.org/sotc/sea_ice.html (accessed 11 October 2010).

National Snow and Ice Data Center, "Weather and Feedbacks Lead to Third Lowest Extent," http://nsidc.org/arcticseaicenews/2010/100410.html (accessed 12 October 2010).

Office of Naval Research, Naval Ice Center, Oceanographer of the Navy, and the Arctic Research Commission. Naval Operations in an Ice-free Arctic Symposium Final Report. Washington, DC: Whitney, Bradley, \& Brown Inc, April 2001.

Patch, John. "Cold Horizons: Arctic Maritime Security Challenges." US Naval Institute Proceedings 135/5/1,275 (May 2009). http://www.usni.org/magazines/proceedings/2009-05/cold-horizons-arcticmaritime- security-challenges (accessed 11 October 2010).

Regehr, Ernie. "NORAD renewal: Further Down the Slippery Slope?" The Ploughshares Monitor 27, no. 3 (Autumn 2006). http://www.ploughshares.ca/libraries/monitor/mons06b.pdf (accessed 11 October 2010).

Renuart, Gene. "How the Military Supports Homeland Security." US Naval Institute Proceedings 135/10/1,280 (October 2009), 26-39.

Renuart, Victor E. "The Enduring Value of NORAD." Joint Forces Quarterly 54, (3rd Qtr 2009): 92-96. https://digitalndulibrary.ndu.edu/cdm4/document.php?CISOROOT=/ndupress\&CISOPTR=21255\&REC=5 (accessed 10 October 2010).

Robbin, Daryl. Arctic Defense Concerns: The Need to Reorganize United States Defense Structure to Meet Threats in a Changing Arctic Region. Newport, RI, Naval War College, May 2010.

Schlauder, W. E. Adapting to a Changing World: The United States, Climate Change, and the Arctic Maritime Commons. Newport, RI, Naval War College, November 2007.

Slaiby, Pete. "Don.t Wait for the Coast Guard in the Arctic." Anchorage Daily News, 29 September 2010. http://www.adn.com/2010/09/29/1478285/dont-wait-for-coast- guard-in-the.html (accessed 11 October 2010).

Smith, Laurence C. "Unfreezing Arctic Assets." Wall Street Journal, 18-19 September 2010, Weekend Journal, W1.

Stewart, George, Scott M. Fabbri, and Adam B. Siegel. JTF Operations Since 1983, CRM 94-42, Alexandria, VA: Center for Naval Analyses, July 1994.

Tritten, James J. "Implications for Multinational Naval Doctrine." In Globalization and Maritime Power, edited by Sam J. Tangredi Washington, D.C.:NDU Press, December 2002, 254-273.

https://digitalndulibrary.ndu.edu/cdm4/document.php?

CISOROOT=/ndupress\&CISOPTR=27639\&REC=18 (accessed 10 October 2010).

United Nations. United Nation Convention on the Law of the Sea of 10 December 1982. Montego Bay, Jamaica: United Nations, December 1982.

U.S. Coast Guard. Report to Congress: U.S. Coast Guard Polar Operations. Washington, DC 2008.

U.S. Coast Guard 17th District Public Affairs. "Multimedia Release: Operation Arctic Crossroads 2010 Concludes in Kotzebue," Public Affairs News Release, 11 August 2010.

http://www.uscgnews.com/go/doc/780/857691/ (accessed 11 October 2010).

U.S. Government Accounting Office. Coast Guard Efforts to Identify Arctic Requirements Are Ongoing, but More Communication about Agency Planning Efforts Would Be Beneficial. GAO-10-870.

Washington, DC: GAO, September 2010.

U.S. Office of the Chairman of the Joint Chiefs of Staff. Homeland Defense. Joint Publication (JP) 3-27. Washington, DC: CJCS, 12 July 2007.

U.S. Office of the Chairman of the Joint Chiefs of Staff. Interagency, Intergovernmental Organization, and Nongovernmental Organization Coordination During Joint Operations, Volume I. Joint Publication (JP) 3-08. Washington, DC: CJCS, 17 March 2006. 
U.S. Office of the Chairman of the Joint Chiefs of Staff. Interagency, Intergovernmental Organization, and Nongovernmental Organization Coordination During Joint Operations, Volume II. Joint Publication (JP) 3-08. Washington, DC: CJCS, 17 March 2006.

U.S. Office of the Chairman of the Joint Chiefs of Staff. Joint Operations. Joint Publication (JP) 3-0. Washington, DC: CJCS, 22 March 2010 with change 2.

U.S. Office of the Chairman of the Joint Chiefs of Staff. Joint Task Force Headquarters. Joint Publication (JP) 3-33. Washington, DC: CJCS, 16 February 2007.

U.S. Office of the Chairman of the Joint Chiefs of Staff. Multinational Operations. Joint Publication (JP) 3-16. Washington, DC: CJCS, 7 March 2007.

U.S. President. Unified Command Plan. Washington, DC: The White House, 23 December 2008. (FOUO).

Yeatman, Richard. "JIATF-South Blueprint for Success." Joint Forces Quarterly 42, (3rd Qtr 2006): 2627. http://www.dtic.mil/doctrine/jel/jfq_pubs/4212.pdf (accessed 11 October 2010).

Material contained herein is made available for the purpose of peer review and discussion and does not necessarily reflect the views of the Department of the Navy or the Department of Defense.

The appearance of external hyperlinks does not constitute endorsement by the United States Department of Defense, the United States Department of the Navy and the Naval Postgraduate School of the linked web sites, or the information, products or services contained therein.

\section{Contacts | Employment | Copyright/Accessibility | Privacy Policy | FOIA | Intranet Access}

This is an official U.S. Navy website.

All information contained herein has been approved for release by the NPS $\underline{\text { Public Affairs Officer. }}$ Contact the Webmaster 